У ДК 327.5(477+470)+341.76(470+439+44)

DOI:10.24144/2078 - 1431.2020. 1(24).27-40

Іван Артьомов,

кандидат історичних наук, доцент,

директор НН Інституту євроінтеграційних досліджень

Ірина Черевко,

викладач природничо-гуманітарного коледжу

ДВНЗ «Ужгородський національний університет»

\title{
УКРАЇНСЬКО-РОСІЙСЬКІ ВІДНОСИНИ 1992-2020 рр.: ЗОВНІШНЬОПОЯІТИЧНИЙ АСПЕКТ
}

Аналізуеться стан двосторонніх відносин у період 1991 - 2020 рр. на основі m. зв. Великого договору між Украӥною та Росією.

Досліджуються основні причини ускладнення взаємовідносин, а саме: невиконання РФ взятих на себе зобов'язань; невизнання існуючих кордонів в акваторіях Азовського і Чорного морів; провокаційне спорудження дамби до українського острова Тузла; дислокація Чорноморського флоту у Севастополі; наслідки Харківських угод 2010 р.; дві «газові війни» Росї з Україною та крайнами ЄС щодо використання украӥнської газотранспортної системи $i$, безумовно, ліквідація ядерного арсеналу України.

Ключові слова: двосторонні відносини, Великий договір, окупація Криму, війна на Сході України, мінський процес, нормандський формат переговорів.

The state of bilateral relations on the basis of the so-called The Great Treaty between Ukraine and Russia in the period of 1991 - 2020 is analyzed.

The main reasons for the complication of the relationship are investigated, in particular: non-fulfillment of obligations undertaken by the Russian Federation; non-recognition of existing borders in the waters of the Azov and Black Seas; provocative construction of a dam to the Ukrainian island of Tuzla; deployment of the Black Sea Fleet in Sevastopol; consequences of the Kharkiv agreements of 2010; Russia's two "gas wars" with Ukraine and EU countries over the use of Ukraine's gas transportation system and, of course, the elimination of Ukraine's nuclear arsenal.

Keywords: bilateral relations, Great Treaty, occupation of Crimea, war in the East of Ukraine, Minsk process, Norman format of negotiations.

Актуальність дослідження. Дослідження проблематики українсько-російських відносин, як правило, завжди розділяло науковців щодо трактування історичного минулого двох великих народів України і Росії починаючи з давніх часів Київської Русі, коли князь Олег проголосив: “Да будетъ Кіевъ матерію городов русскіх» [1].

Дослідники різних часів висвітлювали взаємовідносини України з Росією відповідно до подітичних уподобань існуючої влади, тому об'єктивність їхня часто піддавалася сумніву. 
Зазначимо, що історично російсько-українські відносини розвивалися на міцному підгрунті етнічної спорідненості в рамках православної цивілізації. Однак, зумовлені самою географією системні контакти, а часом і належність українців і росіян до відповідно європейського та євразійського геокультурних просторів формували у них, в деякій мірі, різну ментальність, своєрідні світоглядні цінності.

На сьогоднішній день взаємовідносини між Україною і Росією виходять за рамки відносин дише двох країн. Вони впливають на долю багатьох інших народів і держав, перш за все європейських. Саме тому стан українсько-російських взаємовідносин привертає увагу до них і постійний інтерес громадськості обох народів.

Можемо стверджувати, що стан українсько-російських відносин найбільш грунтовно почав досліджуватися після отримання Україною незалежності у зв'язку з розпадом СРСР.

Російська Федерація як правонаступниця СРСР перед світовим товариством з перших кроків своєї діяльності дала зрозуміти, що колишні союзні республіки, які оголосили про свою незалежність і державну самостійність, в подальшому мають корегувати свої дії з урахуванням інтересів і планів Москви.

Особливо це дали зрозуміти Києву та Мінську, які історично мади багато спільного: географію системних контактів; культурні, гуманітарні, людські стосунки; наявність в прикордонних районах значної кількості національних меншин; історичні та інші зв'язки. Все це давало підстави РФ розглядати Україну як стратегічного партнера і найважливішу країну 3 точки зору встановлення протекторату. Це була стратегічна ціль Російської Федерації - зазначав В. Горбулін [2].

Постановка проблеми. Про важливість України для РФ свідчиди надвагомі аргументи.

По-перше, наявність надпотужного ядерного потенціалу, який поступався лише США та Росії. Адже Україна успадкувала 220 одиниць стратегічних носіїв, зокрема 176 міжконтинентадьних балістичних ракет (МБР) з 1240 боєголовками і 44 важких бомбардувальники ТУ-95, оснащених більш ніж тисячею ядерних крилатих ракет великої діяльності, а також кількасот одиниць тактичної ядерної зброї тощо. Основою ядерної потужності України були 46 твердопаливних міжконтинентальних балістичних ракет SS-24 «Satan» (укр. «Сатана») по десять боєголовок, кожна 3 дальністю ураження цілей більш ніж 10 тис. кілометрів [3].

По-друге, наявність потужного військового комплексу підприємств Південмаша в м. Дніпро, де виготовлялась космічно-ракетна продукція для всього Радянського Союзу; «Арсенала» і «Антонова» в Киеві, інших надпотужних промислових об'єктів, які тісно пов'язані 3 оборонним комплексом Російської Федерації.

По-третє, наявність в України міжнародних транспортно-енергетичних артерій: газопроводів «Прогрес», «Уренгой-Помари-Ужгород»; нафтопроводу «Мир» тощо - об'єктів, які грали стратегічну роль у забезпеченні енергоносіями з Росії найкоротшим шляхом до Центральної та Західної Европи. 
По-четверте, Україна - перша в Европі за територією $(603,7$ км²), п'ята за кількістю населення (52 млн. за переписом 1991 р.). На частку України припадає 40\% европейських чорноземів, вона має запасів вугілля, залізної, марганцевої, уранової руд, інших цінних металів на сотні років.

По-п'яте, Україна географічно з’єднує РФ з СС. Радник з питань національної безпеки адміністрації Президента США Дж. Картера 3. Бжезинський ще у середині 1990-х років зауважив, що Росія не зможе відновитися євразійською імперією без України [4].

Викдад основного матеріалу. Відомо, що основним і базовим документом, що регулював двосторонні відносини України з Росією, був так званий Великий договір від 1 квітня 1999 р. [5].

Після підписання цього документа послідовно було підписано ще 147 міждержавних договорів та угод. Все розпочалося з вирішення долі Чорноморського флоту - найваждивішої проблеми під час укладання нових відносин між Росією та Україною. Завдяки досягнутим домовленостям було створено міжнародно-правову базу для майбутнього російсько-українських відносин - платформу, на якій вони могли розвиватись на благо народів обох держав, миру, стабільності і співробітництва в Европі.

Договір про дружбу, співробітництво і партнерство між Україною та Російською Федерацією складається з 41 статті. У ньому підкреслено, що відносини між нашими дружніми рівноправними і суверенними державами грунтуються «на взаємоповазі і довірі, стратегічному партнерстві і співпраці», що розглядається як важливий чинник зміцнення глобальної та регіональної стабільності. Обидві держави, сказано у Договорі, «будують відносини одна з одною на основі принципів взаємної поваги, суверенної рівності, територіальної цілісності, непорушності кордонів, мирного врегулювання спорів, незастосування сили або загрози силою, включаючи економічні та інші способи тиску, права народів вільно розпоряджатися своєю долею, невтручання у внутрішні справи, додержання прав людини та основних свобод, співробітництва між державами, сумдінного виконання взятих міжнародних зобов'язань, а також інших загальновизнаних норм міжнародного права».

У частині 1 статті 4 [5] зазначено, що держави виходять 3 того, що «добросусідство і співробітництво між ними є важдивими факторами зміцнення стабільності і безпеки в Европі і в усьому світі. Вони здійснюють тісне співробітництво з метою зміцнення міжнародного миру і безпеки. Вони вживають необхідних заходів для того, щоб сприяти процесу загального роззброєння, створенню та зміцненню системи колективної безпеки в Європі, а також посиленню миротворчої ролі ООН і підвищенню ефективності регіональних механізмів безпеки» [6].

Згідно зі ст. 40 [5] Договору, він укладався на десятирічний термін і «його дія буде потім автоматично продовжуватися на наступні десятирічні періоди, якщо жодна з Високих Договірних Сторін не заявить іншій Високій Договірній Стороні про своє бажання припинити його дію шляхом письмового повідомлення не менше ніж за шість місяців до закінчення чергового десятирічного періоду». 
Велику увагу було приділено забезпеченню захисту етнічної, культурної, мовної та релігійної самобутності національних меншин, гарантуванню прав осіб, які належать до націонадьних меншин, повністю і ефективно здійснювати свої права людини і основні свободи та користуватися ними без будь-якої дискримінації в умовах повної рівності перед законом. Також Сторони зобов' язувались забезпечити сприятливі економічні, фінансові і правові умови для підприємницької та іншої господарської діяльності підприемств і організацій, свободу транзиту осіб, вантажів і транспортних засобів через свої території відповідно до загальновизнаних норм міжнародного права. Країни зобов' язувадись приділити особливу увагу розвитку співробітництва в забезпеченні функціонування національних паливно-енергетичних комплексів, транспортних систем і систем зв'язку та інформатики, сприяючи збереженню, раціональному використанню і розвитку комплексів та єдиних систем, що склалися у цих галузях.

На сьогоднішній день існує багато суперечок навколо статті 6 Договору, де йдеться про те, що Сторони зобов'язуються утримуватися «від участі або підтримки будь-яких дій, спрямованих проти другої Високої Договірної Сторони», «не укладати 3 третіми країнами будь-яких договорів, спрямованих проти другої Сторони», а також не допускати, «щоб іï територія була використана на шкоду безпеці другої Сторони».

18 вересня 2008 р. президент РФ Д. Медведєв, приймаючи в Олександрійському залі Кремля вірчі грамоти у посла України в Росії К. Грищенка, заявив: «Народи Росії і України нерозривно зв' язують по-справжньому братерські відносини і особливі відчуття пошани і взаємної довіри» [7]. Отже, незважаючи на взаємні претензії, Україна та Росія все ж таки продовжили дію Договору.

Україна була налаштована будувати відносини з Росією на принципах добросусідства, рівноправ'я, 3 повагою до незалежності кожного 3 народів, права суверенної нації формувати свою політику з ключових внутрішніх і зовнішніх питань. 1 жовтня 2008 р. було зроблено правову пролонгацію функціонування цього Договору ще на 10 років, таким чином, і Україна, і Росія з розумінням підійшли до того, наскільки важдиві основоположні принципи цієї Угоди для розвитку у перспективі наших двосторонніх відносин [8].

Подальші дії РФ щодо України засвідчили системне односторонне трактування умов Великого договору на основі не рівноправного партнера, а «меншого» брата. Наведемо підтвердження цього.

По-перше, починаючи з 2006 р. Росія для реалізації своїх цілей застосовує комплексний підхід з використанням впливу на Україну в енергетичній, економічній і гуманітарно-інформаційній сферах. Яскравим прикладом такого тиску стали відомі події «газових війн» 2005-2006 рр. та 2008-2009 рр. [9].

По-друге, відбувається послідовна компрометація подітики України в цих сферах від двосторонніх відносин до впливу на геоподітично-гдобальному рівнях [10]. 
По-третє, основним полігоном для відпрацювання політики Кремля щодо України став Крим з метою отримання вирішального впливу на політику Києва, особливо в контексті загроз національній безпеці [11].

Підписання у 2010 р. Угоди між Україною та Російською Федерацією 3 питань перебування Чорноморського флоту Російської Федерації на території України (так звані «Харківські угоди») засвідчило започаткування нового етапу тиску на Україну, особливо в контексті базування у Севастополі Чорноморського флоту [12].

Широкий спектр прихованих загроз для України від РФ можна продовжувати, але найбільш синтезовано вони згруповані в статті для «Дзеркала тижня» екссекретаря Ради національної безпеки України академіка Володимира Горбуліна і доктора політичних наук Олександра Литвиненка [2]. Російський наступ на Київ, на їх думку, розпочнеться упродовж найближчих п'яти років (прим. - стаття вийила друком у 2009 р.). На думку експертів, нові плани щодо України були озвучені у серпневій заяві російського президента Дмитра Медведєва і у близькому за змістом розгорнутому виступі депутата Державної думи РФ Костянтина Затуліна у травні 2009 року. «Йдеться фактично про ультиматум, що збереження територіальної цілісності України зумовлюеться їі переходом до «особливих відносин» 3 РФ, а фактично - до російського протекторату над слабкою Україною», - зазначають Горбулін і Литвиненко.

При тому, на думку фахівців, у Кремля поки відсутній детальний план досягнення цієї мети, і Росія готова діяти ситуативно. «Мова не про розроблений план дій, а саме про стратегічні цілі та завдання, напрями і пріоритети. Поточні конкретні дії Москви визначатимуться перебігом ситуації і насамперед реакцією України», - наголошують експерти [2]. Експерти не виключали, що протекторат над Україною не є кінцевою зовнішньополітичною ціллю Російської Федерації. «Не виключено, що встановлення протекторату може розглядатися лише як перехідний етап для подальшого територіального розділу України, ймовірно на три частини, за моделлю, оприлюдненою, швидше за все, російською розвідкою в італійському геополітичному журналі «Limes», - припускали фахівці.

У зазначеній моделі, за словами Горбуліна і Литвиненка, йдеться про пряме включення Півдня і Сходу України до складу РФ, створення маріонеткового уряду на теренах Центральної України та відмежування від Західної як основного «порушника спокою». «Агресивна політика Кремля щодо України викликана не діями Києва, а потребами Росії, як їх усвідомлює нинішне керівництво держави. Тобто навіть кардинальна зміна Україною політичного курсу не призведе до істотної корекції російської політики та не відмінить уже визначених цілей», - відзначали експерти [13].

«Підпорядкування України, або принаймні їі південно-східної частини, Кремлю має істотно поліпшити ситуацію в РФ. Зокрема, пом'якшити демографічні проблеми, забезпечити надійний транзит енергоносіїв до Европи, значно збільшити економічний потенціал, насамперед у машинобудуванні, сільському господарстві, унеможливити отримання США те- 
риторіального плацдарму у безпосередній близькості від Москви», - констатують експерти.

Відомо, що у Мінській угоді щодо утворення СНД було закріплено положення про взаємне визнання і поважання територіальної цілісності країн-учасниць Співдружності, недоторканності їх кордонів. У заяві Верховної Ради України 20 грудня 1991 р. $з$ приводу Угоди про Співдружність незалежних держав зазначалося: «Кордон між Україною - з одного боку, та Росією і Білоруссю - $з$ іншого, є державним кордоном України, який є недоторканним. Дінія його проходження, визначена Договором між Україною і Росією 1990 р., дишається незмінною незалежно від того, чи є Україна стороною Угоди, чи ні» [14].

Довжина українсько-російського кордону - 2484 км. На середину 1996 р. тут функціонувало 60 пунктів пропуску, з них залізничних - 15, автомобільних - 44 і одна паромна переправа. Планувалось після належного облаштування відкрити ще сім автомобільних і два залізничних пункти пропуску. На літо 1998 р. обидві сторони домовидись про оформлення правового статусу акваторії Азовського моря і Керченської протоки і завершення делімітації державного кордону на 1999 р. На січень 2002 р. Україна повністю делімітувала сухопутний кордон з Росією [15].

Насторожуючими факторами у взаємовідносинах двох держав стали заяви С. Примакова - глави МЗС Росії про те, що кордони держав, які утворились внаслідок розвалу СРСР, не фіксуються і не гарантуються Гельсінськими домовленостями. Ця заява - свідчення закладання підгрунтя для майбутніх переділів територій 3 колишніми сусідами по СРСР, в т.ч. із Україною.

Тричі у 1992 р. МЗС України надсилало до МЗС Російської Федерації ноти 3 проєктом Угоди про делімітацію українсько-російського кордону, а також пропозиції стосовно початку його правового оформлення. Російська сторона від усіх цих пропозицій ухилялась. Влітку 1992 р. російський міністр А.Козирєв попередив, що цілісність української території не може бути незаперечним фактом.

Російський парламент 9 липня 1993 р. прийняв постанову «Про статус міста Севастополя», в якій наголошувалось, що місто має перебувати у російському підпорядкуванні, оскільки при передачі Кримської області в 1954 р. зі складу Росії до складу України Указ Президії Верховної Ради РРФСР 1948 р. про безпосередне підпорядкування Севастополя Російській Республіці не визнано таким, що втратив чинність. Це рішення було однозначно оцінено як агресивний подітичний акт, який суперечить нормам міжнародного права, спрямований на порушення кордонів і територіальної цілісності України. Позицію України підтримала світова спільнота, передусім Рада Безпеки ООН. Вона визнала такий крок несумісним із взаємними зобов'язаннями РФ та України про непорушність кордонів, таким, що суперечить цілям і принципам Статуту ООН, а відтак не має юридичної сили [16].

Наприкінці січня 1996 р. у м. Сочі відбулась зустріч делегацій прикордонних відомств України та РФ. За підсумками зустрічі було підписано 
протоколи про спільний прикордонний і митний контроль між Україною і Російською Федерацією.

Наступним недружнім кроком Росії щодо України став конфдікт навколо о. Коса Тузла восени 2003 р., коли почалося спорудження дамби Росією в Керченській протоці, де планувалось встановлення російської прикордонної застави. Незважаючи на те, що Росія тоді відступила, дискусії навколо кордонів між двома державами в Азовському морі не вщухають до сьогодні. 20 квітня 2004 р. Верховна Рада та Державна Дума одночасно ратифікували Угоду про українсько-російський державний кордон між Україною та РФ. Того ж дня було ратифіковано й Угоду про співробітництво у використанні Азовського моря та Керченської протоки.

25 квітня 2005 р. в Києві відбувся двадцятий раунд переговорів державних делегацій України та Росії з проблем розмежування Азовського моря та Керченської протоки, під час яких РФ не погодилася 3 позицією України відносно того, що кордон у Керченській протоці має збігатися 3 лінією колишнього адміністративно-територіального кордону між УРСР та РРФСР. І тут пропозиції російської сторони, які зводяться до ідеї спільного використання або делімітації лише дна Азовського моря та Керченської протоки, є цілком неприйнятними, оскільки суперечать інтересам української сторони, які вимагають встановлення фіксованих державних кордонів, у тому числі на водній поверхні.

Таким чином, незважаючи на те, що сухопутний кордон між Україною і Російською Федерацією та кордон у районі Керченської протоки, як і всі інші ділянки морського кордону між Україною і РФ, закріплені низкою міждержавних українсько-російських договорів і повністю відповідають конвенції ООН по міжнародному морському праву, Росія проводить послідовну політику тиску та блокування портів України. Так, у 2019 р. споруджується міст, що з'єднує Крим з материковою частиною Росії, через що встановлюеться блокада українських портів на узбережжі Азовського моря і здійснюеться значний економічний вплив на Україну [17].

Отримання Росією статусу м. Севастополь як військово-морської бази російського Чорноморського флоту та домовленості щодо його перебування значно більше задовольняли РФ, ніж Україну.

Статус Чорноморського флоту Російської Федерації в Україні, його основні параметри, умови перебування та порядок розрахунків визначаються трьома основними документами: Угодою між Російською Федерацією та Україною про статус та умови перебування Чорноморського флоту Російської Федерації на території України (Угода про статус ЧФ), Угодою між Україною і Російською Федерацією про параметри поділу Чорноморського флоту (Угода про поділ ЧФ) та Угодою між Урядом України і Урядом Російської Федерації про взаємні розрахунки, пов' язані з поділом Чорноморського флоту та перебуванням Чорноморського флоту Російської Федерації на території України (Угода про розрахунки за ЧФ). Усі три були підписані у 1997 р. та набули чинності у 1999 р. Ці документи мають рамковий характер і з конкретних питань відсилають або до українського законодавства, або до окремих угод між сторонами. Останніх передбачено 
принаймні десять. Існуе також низка допоміжних нормативних актів, які не згадуються у базових угодах [18].

Угодою про статус встановлювалось, що Чорноморський флот РФ 3 головною базою, розташованою у Севастополі, перебуватиме в Україні принаймні до 2017 р. Після цього, якщо жодна зі сторін не вийде з Угоди про статус у спосіб письмового попередження іншої сторони не пізніше ніж за рік до закінчення терміну іiі дії, весь комплекс угод про ЧФ автоматично продонгується на наступні п'ять років (всі угоди, окрім Угоди про розрахунки, чинні протягом терміну дії Угоди про статус).

Сдід відзначити, що найскладніші юридичні проблеми щодо тимчасового базування ЧФ РФ стосувались оформлення договорів оренди відповідно до вимог внутрішнього законодавства України і узгодження умов використання гідрографічного-навігаційного обладнання [14, с.115].

Харківські угоди 2010 р. [12] України з РФ щодо базування російського ЧФ у Севастополі передбачали продовження угод між сторонами до 2040 р., що було вкрай негативно сприйнято НАТО.

Серед інших проблем співпраці двох країн залишається проблема статусу українських арсеналів, де за радянських часів зберігадися боєприпаси різних систем озброєння , які були вивезені 3 колишніх країн соціадістичного табору, - Угорщини, Чехії, Польщі у 1991-1993 рр.

Саме через поганий стан арсеналів проблема утилізації надлишкової кількості боєприпасів і ракет в Україні є гострою, а наслідки аварій останніх років - такими важкими. Прийнята постановою КМУ № 472 від 28 червня 1995 р. Програма забезпечення живучості та вибухопожежобезпеки арсеналів, баз і складів озброєння, ракет і боєприпасів Збройних Сил України на 1995-2015 роки хронічно не виконується через недофінансування [14, с.116].

Як наслідок - серія майже щорічних підривів складів із боєприпасами. Аише за час військових дій на Сході України пролунало 5 надпотужних підривів на військових складах. Зокрема були інциденти в:

- Новобогданівці біля Мелітополя;

- Калинівці Вінницької області;

- Балаклії Харківської області;

- Ічні Чернігівської області.

На цих складах зберігалось величезна кількість боєприпасів (від 15 до 70 тис тонн).

Прямі збитки від вибухів на складах дише у 2018 р. становили більше 2 млрд. дол. США.

Серед існуючих проблем двосторонніх відносин одна із найбільш актуальних була пов'язана із поставкою з Росії енергоносіїв для України і країн Євросоюзу починаючи з 2006 р.

Европейська спільнота втрете за останні десять років переживає газову війну Росії з Україною. Апофеоз першого газового конфлікту припав на 1 січня 2006 р., коли після тривадих та складних перемовин щодо ціни на блакитне паливо (для України газ подорожчав з 50 до 230 доларів за тис. кубометрів) домовленості так і не було досягнуто. Росія, звинува- 
тивши НАК «Нафтогаз України» у крадіжці природного газу, припинила поставки вуглеводнів до України, втім, продовжила їх транзит до Европи. Конфлікт вирішився досить швидко, вже 4 січня Україна «святкувала» підписання нового контракту, де ціна за російський газ сягнула 95 дол. за тис. кубометрів [9].

Фінал другого українсько-російського газового конфлікту 2009 р. традиційно припав на січень. Чинником конфдіктного протистояння обох держав стала компанія-посередник «РосУкрЕнерго». Власне, українська сторона, посилаючись на подорожчання поставок газу, вирішила в односторонньому порядку відмовитись від послуг посередника. Натомість Москва виставила Києву рахунок у розмірі 2,4 млрд дол. як заборгованість за надані послуги. У відповідь тогочасний прем'єр-міністр Юлія Тимошенко заявила, що борг має сплатити «Рос-УкрЕнерго».

Газові суперечки між Росією та Україною завершилися підписанням угод, які регулювали постачання газу в Україну і розблокували транзит палива до Европи. Угоди мали довготерміновий характер і були розраховані на 10 років. Один із принципових пунктів домовленостей - перехід 31 січня 2009 р. до європейського принципу формування ціни на газ. Відтоді вона залежить від вартості інших енергоносіїв на світових ринках і розраховуватиметься за формулою. Тодішній прем'єр-міністр України Юлія Тимошенко вважала, що ціна на газ для українських споживачів у 2009 році - суттєве досягнення переговорного процесу між Україною та Росією. «Те, що вдалося здобути, я вважаю серйозним досягненням у переговорному процесі між Україною і Росією, серйозними поступками назустріч один одному», - підкреслила прем'єр-міністр [19].

Зазначимо, що важливість Угоди полягає в тому, що вона давала можливість завантаження на 10 років української газотранспортної системи шляхом стабільної прокачки газу в ЕС [20]. Крім того, НАК «Нафтогаз України» і російське ВАТ «Газпром» підписали доповнення до контракту купівлі-продажу газу від 19 січня 2009 р. про постачання газу за ціною 289,5 дол. за тис. кубометрів, тоді як перед цим вона становила понад 400 дол. США, при цьому коефіцієнт вартості російського газу для України буде переглядатися і затверджуватися щоквартально. Водночас було обговорено формат та ціну прокачки газу до країн ЕС [21]. Втім, як показав час, райдужні заяви та висока оцінка підписання доповнень до контракту купівлі-продажу газу у 2009 р. були далекими від рівноправних і взаємовигідних для України, на що, до речі, звернули увагу експерти країн $\mathrm{EC}$, що працювали на «газовому» ринку і які розуміли існуючі ризики для стабільного «прокачування» російського газу в ЄС через українську ГТС [22].

Важливим знаком для України щодо стратегії Росії по відношенню до сусідів стало рішення Росії про визнання незалежності Південної Осетії та Абхазї. Україна зайняла однозначну позицію, заявивши про небажаність участі кораблів Чорноморського флоту, що тимчасово дислоковані на території України, у військовому конфлікті у Південній Осетії. 3 метою запобігти втягненню у збройний конфлікт Україна повідомляла, 
що залишатиме за собою право згідно з нормами міжнародного права i законодавства України заборонити повернення суден, які брали участь у конфлікті, в українські порти.

Поточну ситуацію у двосторонніх відносинах України та Росії того часу влучно охарактеризував Анатолій Зленко - двічі очільник МЗС України [23], У такій непростій ситуації важливу роль відігравала зовнішньополітична діяльність України. За оцінками А. Зленка, «події останніх тижнів, зокрема обмін «люб'язностями» 3 приводу висилки російських і українських дипломатів, указують на серйозні зрушення в українсько-російських відносинах. За великим рахунком, це своєрідний виклик стратегічному партнерству двох країн і, подобається це чи ні, нагнітання напруженості на роки наперед із використанням різноманітних, часто не дипломатичних, засобів для подальшого домінування у двосторонніх відносинах».

Рішення президента РФ не направляти в Україну нового посла означає не що інше як небажання Росії шукати вихід із нинішнього глухого кута. Складається враження, що російська сторона не зовсім конструктивно підходить до побудови відносин із Україною. Новий посол РФ в Україні міг би внести свіжий струмінь у характер двосторонніх контактів і, головне, розібратися з проблемами, які провокують сповзання в невизначеність перспектив нашого співробітництва. Ситуації, схожі на ту, яка склалася, характерні для стану відкритої ворожнечі між країнами» [23].

Наш північний сусід Росія, як і раніше, залишається головним агентом впливу на політичне та економічне життя України. найбільшою мірою турбують РФ такі сфери діяльності, як: співробітництво в галузі енергетичної безпеки, перебування на території України Чорноморського флоту, статус російської мови в Україні, інтерпретація спірних питань історичного минулого тощо. Але це не нові питання, вони постійно присутні в діалозі між представниками двох країн. Для їх вирішення достатньо напрацьованої за роки незалежності договірно-правової бази. Бракуе політичної волі, причому по обидва боки.

Наслідками ситуації, що склалася за часів президенства $А$. Кучми (1994-2004 рр.), стало чітке визначення зовнішньополітичного курсу на європейську та євроатлантичну інтеграцію. Саме Послання Президента А. Кучми до Верховної Ради «Европейський вибір України» [24] стало важливою віхою на шляху формування євроінтеграційного та євроатлантичного поступу України.

Логічність та закономірність глобальних зовнішньополітичних орієнтирів України пояснюється тим, що наша держава є важливою складовою глобальних процесів. Геостратегічне положення України, яка знаходиться на перехресті різновекторних глобальних інтересів Росї-СС-США, відіграє важливу роль між західною і російсько-евразійською цивілізаціями. Для натівської Европи східні кордони України є лінією роздому Европи з Росією, а Росія вбачає у західних кордонах України лінію роздому між НАТО та СНД - простором, який вважає зоною своїх інтересів [25].

Спроби РФ повернути Україну в зону впливу своїх інтересів до єдиного економічного простору та євразійської цивілізацї провалилась. Це ста- 
ло зрозуміло у 2004 р., коли відбулася Помаранчева Революція в Україні, та 2013-початку 2014 р. - Революція Гідності.

Окупація Криму в процесі т. зв. «гібридної війни» РФ та окупація окремих областей Донбасу сепаратистами знаменували початок найбільш гострого протистояння між двома державами, яке, на превеликий жаль, досі триває.

Збулись передбачення Володимира Горбуліна, який ще у 2009 р. зазначав: «У Кремлі усвідомлюють, що історичне «вікно можливостей» щодо України для Москви доволі коротке і може зачинитися вже десь після 2015 р., після становлення нового покоління українських еліт. Отже, «наступ на Київ» розгорнеться вже найближчим часом і буде рішучим та безпощадним».

Знаковими стали підписані 5 вересня 2014 р. Мінські угоди, які передбачали припинення вогню, та прийняття законів «Про особливий порядок місцевого самоврядування в окремих районах Донецької та Ауганської областей» і відбудову економіки Донбасу, які були затверджені Верховною Радою України 16 вересня 2014 р. Виконати домовденості передбачалось до кінця 2015 р. Втім, Мінські угоди до сьогодні є спільною площадкою для переговорів у нормандському форматі. Остання зустріч на найвищому рівні в такому форматі відбулась у грудні 2019 р. за участі Президента України В. Зеленського, президента Росії В. Путіна, президента Франції Е. Макрона та канцлера Німеччини А. Меркель [26].

У надзвичайно складних умовах пандемії COVID-19 та карантинних заходів проходить підготовка чергової зустрічі на найвищому рівні в рамках «нормандської четвірки» у 2020 р. Маємо сподівання на успішне проведення цієї зустрічі та прийняття доленосних для України рішень.

\section{СПИСОК ВИКОРИСТАНИХ ДЖЕРЕ $Д$}

1. Карамзин Н.М. История государства Российского: Книга первая: Олег правитель. Тома I-IV. М.: «Книга», 1988. С.75 (репринтное воспроизведение издания 1842-1844 гг.)

2. Горбулін В., Литвиненко О. Стратегічною ціллю РФ є встановлення протекторату над Україною. URL: https://dt.ua/POLITICS/eksperti_strategichnoyu_tsillyu_ rf_e_vstanovlennya_protektoratu_nad_ukrayinoyu.html

3. Горбулин В.П. Мой путь в зазеркалье. Не только путевые заметки. Брайт-Букс, 2019. 280 с. С. 241.

4. Бжезинський 3. Велика шахівниця. Американська першість та їі стратегічні перспективи. Basic Books, 1997.

5. Договір про дружбу, співробітництво і партнерство між Російською Федерацією і Україною від 31травня 1997 р. / Верховна Рада України [сайт]. URL: http:// zakon4.rada.gov.ua/laws/show/643_006.

6. Закон України «Про міжнародні договори України»від 29 червня 2004 року // Відомості Верховної Ради України. 1992. № 10. Ст. 137.

7. Україна хоче отримати від «Газпрому» гарантії завантаження ГTС газом. URL: // http://www.newsru. ua/finance/21aug2010/gaz.html.

8. Медведєв вважає, що ніщо не завадить братерським відносинам України та Роciï. URL: http://kyiv.comments. ua/country/2008 /09/18/143432.html. 
9. Ісевич $Є$. Україна-Росія: газові війни, а що далі? // Геополітика України: історія і сучасність: збірник наукових праць. Вип. 2 (15). /ред. кол.: І.В.Артьомов (голова) та ін. Ужгород: ДВНЗ «УжНУ», 2015. 244 с. С.69-72.

10. Тодоров І., Тодорова Н. Українські міжрегіональні відмінності в контексті російської агресії проти України в 2014-2015 рр. // Геополітика України: історія і сучасність: збірник наукових праць. Вип. 1 (14). / ред. кол.: І.В. Артьомов (голова) та ін. Ужгород: ДВНЗ «УжНУ», 2015. 236 с. С. 29-42.

11. Власюк О. В., Кононенко С. В. Актуальні аспекти вдосконалення моделі національної безпеки України // Стратегічна панорама: щоквартальний науково-практичний журнал / за заг. ред. Горбуліна В.П. Київ, 2017, Вип. 1. С.17-23.

12. Угода між Україною та Російською Федерацією з питань перебування Чорноморського флоту Російської Федерації на території України (укр/рос). URL: https://zakon.rada.gov.ua/laws/show/en/643_359

13. Експерти: Агресія проти України зумовлена внутрішньою ситуацією в РФ. URL: https://dt.ua/POLITICS/eksperti_agresiya_proti_ukrayini__ zumovlena_vnutrishnoyu_situatsieyu_v_rf.html

14. Король І., Господар М. Особливості сучасних українсько-російських відносин та їх вплив на геополітичну ситуацію в Європі // Геополітика України: історія і сучасність: збірник наукових праць. Вип. 1. Ужгород: Ліра, 2009. 312 с. С.106-128.

15. Геоподітика: Україна в міжнародних відносинах. Проблема кордонів у СНД. URL: http://readbookz.com/book/183/6468.html

16. Григорець Т. Основні етапи та тенденції розвитку українсько-російських відносин 1991 -2006 років. URL:http://www.niss.gov.ua/book/Vlasyuk_mon/09-2.pdf

17. П'ять загроз Керченського мосту для України і не тільки. URL: https://www. dw.com/uk/

18. Притула В. Чи гарантуе Чорноморський флот Росії безпеку України? URL: http://www.radiosvoboda.org /content/Article /1565421.html

19. Тимошенко Ю.: Українсько-російські газові переговори 2009 року - приклад того, як необхідно будувати міждержавні відносини. URL: http://www.tymoshenko. com.ua/ukr/news/first/6869/

20. Клюк Б.О. Газотранспортна система України:надійність ібезпека транзиту газудо Европи. URL: http://www.utg.ua/wp-content/uploads/2010/11/03112010-Ukrtransgas-ukr.pdf

21. Озвучено новую цену на газ для Украины: 268,5 доли. за тыс. кубометров. URL: https://zn.ua/ECONOMICS/naftogaz-i-gazprom-podpisali-dopolnenie-k-kontraktu-na-postavku-gaza-135249_.html

22. В ЕС осторожно прокомментировали договоренности Януковича-Путина. URL: https://news.liga.net/politics/news/v_evrokomissii_privetstvovali_dogovorennosti_yanukovicha_putina

23. Зленко А. Україна в мінливому світі // Дзеркало тижня №31 (759). $22-28$ серпня 2009 p.

24. Європейський вибір. Концептуальні засади стратегії економічного та соціального розвитку України на 2002-2011 роки. URL: https://zakon.rada.gov.ua/laws/show/ n0001100-02\#Text

25. Артьомов І.В. Євроінтеграційний аспект української геополітики// Україна на перехресті геополітичних інтересів: актуальні аспекти: збірник наукових праць за матеріалами міжнародної наукової конференції / відп. ред. І.В. Артьомов. Ужгород: Ліра, 2007. С.25.

26. Про що домовилися учасники «нормандської четвірки» в Парижі. URL: https:// zaxid.net/statti_tag50974/ 


\section{REFERENCES}

1. Karamzin, N.M. (1988). Istoriya gosudarstva Rossiyskogo: Kniga pervaya: Oleg pravitel' [History of the Russian State: Book One: Oleg The Ruler]. Vols. I-IV. M.: «Kniga» (reprintnoye vosproizvedeniye izdaniya 1842-1844 gg. - reprint reproduction of the edition of 1842-1844), [in Russian].

2. Horbulin, V., \& Lytvynenko, O. Stratehichnoyu tsillyu RF ye vstanovlennya protektoratu nad Ukrayinoyu [The strategic goal of the Russian Federation is to establish a protectorate over Ukraine]. Retrieved from https://dt.ua/POLITICS/eksperti_strategichnoyu_tsillyu_rf_e_vstanovlennya_protektoratu_nad_ukrayinoyu.html [in Ukrainian].

3. Gorbulin, V.P. (2019). Moy put' v zazerkal'ye. Ne tol'ko putevyye zametki [My way through the looking glass. Not just travel notes]. Brayt-Buks. P. 241 [in Russian].

4. Bzhezyns'kyy, Z. (1997). Velyka shakhivnytsya. Amerykans'ka pershist' ta yiyi stratehichni perspektyvy. [The Grand Chessboard: American Primacy and Its Geostrategic Imperatives]. Basic Books [in Ukrainian].

5. Dohovir pro druzhbu, spivrobitnytstvo i partnerstvo mizh Rosiys'koyu Federatsiyeyu $i$ Ukrayinoyu vid 31travnya 1997 r. [Treaty of Friendship, Cooperation and Partnership between the Russian Federation and Ukraine of May 31, 1997]. (1997). Verkhovna Rada Ukrayiny. Retrieved from http://zakon4.rada.gov.ua/laws/show/643_006 [in Ukrainian].

6. Zakon Ukrayiny «Pro mizhnarodni dohovory Ukrayiny» vid 29 chervnya 2004 roku [Law of Ukraine «On International Treaties of Ukraine» of June 29, 2004]. (2004). Retrieved from https://zakon.rada.gov.ua/laws/show/1906-15\#Text [in Ukrainian].

7. Ukrayina khoche otrymaty vid «Hazpromu» harantiyi zavantazhennya HTS hazom [Ukraine wants to receive guarantees from Gazprom to load the GTS with gas]. Retrieved from http:// www.newsru. ua/finance/21aug2010/gaz.html [in Ukrainian].

8. Medvedyev voazhaye, shcho nishcho ne zavadyt' braters'kym vidnosynam Ukrayiny ta Rosiyi [Medvedev believes that nothing will hinder the fraternal relations between Ukraine and Russia]. Retrieved from http://kyiv.comments. ua/country/2008/09/18/143432.html. [in Ukrainian].

9. Isevych, YE. (2015). Ukrayina-Rosiya: hazovi viyny, a shcho dali? [Ukraine and Russia: gas wars but what in future?]. I.V. Artyomov (Eds.). Heopolityka Ukrayiny: istoriya i suchasnist' - Geopolitics of Ukraine: History and Modern Times, 2 (15), 69-72. Uzhhorod: DVNZ «UzhNU» [in Ukrainian].

10. Todorov, I., \& Todorova, N. (2015). Ukrayins'ki mizhrehional'ni vidminnosti v konteksti rosiys'koyi ahresiyi proty Ukrayiny v 2014-2015 rr. [Ukrainian interregional differences in the context of Russian aggression to Ukraine in 2014-2015]. I.V. Artyomov (Eds.). Heopolityka Ukrayiny: istoriya i suchasnist' - Geopolitics of Ukraine: History and Modern Times, 1 (14), 29-42. Uzhhorod: DVNZ «UzhNU» [in Ukrainian].

11. Vlasyuk, O. V., \& Kononenko, S.V. (2017). Aktual'ni aspekty vdoskonalennya modeli natsional'noyi bezpeky Ukrayiny [Actual aspects of improving the national security model of Ukraine]. V.P. Horbulin (Eds.). Stratehichna panorama - Strategic Panorama, 1, 17-23 [in Ukrainian].

12. Uhoda mizh Ukrayinoyu ta Rosiys'koyu Federatsiyeyu z pytan' perebuvannya Chornomors'koho flotu Rosiys'koyi Federatsiyi na terytoriyi Ukrayiny (ukr/ros) [The Agreement between the Russian Federation and Ukraine on the Status and Conditions of the Presence of the Russian Federation Black Sea Fleet on the territory of Ukraine]. Retrieved from https://zakon.rada.gov.ua/laws/show/en/643_359 [in Ukrainian].

13. Eksperty: Ahresiya proty Ukrayiny zumovlena vnutrishn'oyu sytuatsiyeyu v RF [Experts: The aggression against Ukraine is due to the internal situation in Russia]. Retrieved from https://dt.ua/POLITICS/eksperti_agresiya_proti_ukrayini_zumovlena_vnutrishnoyu_situatsieyu_v_rf.html [in Ukrainian].

14. Korol', I., \& Hospodar, M. (2009). Osoblyvosti suchasnykh ukrayins'ko-rosiys'kykh vidnosyn ta yikh vplyv na heopolitychnu sytuatsiyu v Yevropi [Features of modern 
Ukrainian-Russian relations and their impact on the geopolitical situation in Europe]. Heopolityka Ukrayiny: istoriya i suchasnist' - Geopolitics of Ukraine: History and Modern Times, 1, 106-128. Uzhhorod: Lira [in Ukrainian].

15. Heopolityka: Ukrayina v mizhnarodnykh vidnosynakh. Problema kordoniv u SND [Geopolitics: Ukraine in international relations. The problem of borders in the CIS]. Retrieved from http://readbookz.com/book/183/6468.html [in Ukrainian].

16. Hryhorets', T. Osnovni etapy ta tendentsiyi rozvytku ukrayins'ko-rosiys'kykh vidnosyn 1991-2006 rokiv [The main stages and trends in the development of Ukrainian-Russian relations of 1991-2006]. Retrieved from http://www.niss.gov.ua/book/Vlasyuk_mon/092.pdf [in Ukrainian].

17. P'yat' zahroz Kerchens'koho mostu dlya Ukrayiny i ne til'ky [Five threats to the Kerch Bridge for Ukraine and beyond]. Retrieved from https://www.dw.com/uk/ [in Ukrainian].

18. Prytula, V. Chy harantuye Chornomors'kyy flot Rosiyi bezpeku Ukrayiny? [Does the Russian Black Sea Fleet guarantee the security of Ukraine?]. Retrieved from http://www.radiosvoboda.org /content/Article /1565421.html [in Ukrainian].

19. Tymoshenko, YU.: Ukrayins'ko-rosiys'ki hazovi perehovory 2009 roku - pryklad toho, yak neobkhidno buduvaty mizhderzhavni vidnosyny [Ukrainian-Russian gas talks in 2009 - an example of how to build interstate relations]. Retrieved from http://www.tymoshenko. com.ua/ukr/news/first/6869/ [in Ukrainian].

20. Klyuk, B.O. Hazotransportna systema Ukrayiny: nadiynist' i bezpeka tranzytu hazu do Yevropy [Ukraine's gas transportation system: reliability and security of gas transit to Europe]. Retrieved from http://www.utg.ua/wp-content/uploads/2010/11/03112010-Ukrtransgas-ukr.pdf [in Ukrainian].

21. Ozvucheno novuyu tsenu na gaz dlya Ukrainy: 268,5 doll. za tys. Kubometrov [New gas price for Ukraine announced: 268.5 dollars per thousand cubic meters]. Retrieved from https:// zn.ua/ECONOMICS/naftogaz-i-gazprom-podpisali-dopolnenie-k-kontraktu-na-postavku-gaza-135249_html [in Russian].

22. VYES ostorozhno prokommentirovali dogovorennosti Yanukovicha-Putina [he EU cautiously commented on the agreement of Yanukovych-Putin]. Retrieved from https://news.liga.net/ politics/news/v_evrokomissii_privetstvovali_dogovorennosti_yanukovicha_putina [in Russian].

23. Zlenko, A. (2009). Ukrayina v minlyvomu sviti [Ukraine in a changing world]. Dzerkalo tyzhnya-Mirror of the week, 31 (759) [in Ukrainian].

24. Yevropeys'kyy vybir. Kontseptual'ni zasady stratehiyi ekonomichnoho ta sotsial'noho rozvytku Ukrayiny na 2002-2011 roky [European choice. Conceptual bases of strategy of economic and social development of Ukraine for 2002-2011]. Retrieved from https://zakon.rada.gov. ua/laws/show/n0001100-02\#Text [in Ukrainian].

25. Art'omov, I.V. (2007). Yevrointehratsiynyy aspekt ukrayins'koyi heopolityky [European integration aspect of Ukrainian geopolitics]. I.V. Art'omov (Eds.), Ukrayina na perekhresti heopolitychnykh interesiv aktual'ni aspekty - Ukraine at the crossroads of geopolitical interests: current aspects: Proceedings of the International Scientific and Practical Conference. (p. 25). Uzhhorod: Lira [in Ukrainian].

26. Pro shcho domovylysya uchasnyky «normands'koyi chetvirky» v Paryzhi [What was agreed by the participants of the "Quartet of Normandy" in Paris]. Retrieved from https://zaxid. net/statti_tag50974/[in Ukrainian]. 